\title{
SOFT SKILLS FORMATION THROUGH THE PRISM OF UNIVERSITY STUDENTS' VIEW: ANALYSIS OF SURVEY RESULTS
}

\author{
Liubov Lokhvytska \\ Hryhorii Skovoroda University in Pereiaslav, Ukraine \\ Nataliia Martovytska \\ The Bohdan Khmelnytsky National University of Cherkasy, Ukraine \\ Olena Kolomiiets \\ The Bohdan Khmelnytsky National University of Cherkasy, Ukraine
}

\begin{abstract}
Fundamental changes in the educational paradigm of the Ukrainian education modern system have led to a revision of the process of improving the university students' professional training. The issue of students' soft skills formation as mandatory for the diversification of career opportunities in the labor market is relevant. Unification with European standards has led to the necessity to fill the new content of university education to ensure personal development and self-development of future professionals in the course of mastering fundamental and special disciplines and the soft skills formation, which determines the novelty of the issue. The purpose of the study was to carry out a theoretical analysis of the problem of students' soft skills formation and empirical study of the students' attitude (pedagogical specialty) of Ukrainian universities to this process in the context of preparation for their future career. The main method was a survey conducted by respondents filling out an author's questionnaire "What is an ideal preschool teacher?" in electronic form on the online platform Google. Students of the specialty 012 "Preschool Education" of the first (bachelor's) level of higher education (1-4 years of study) from 2 Ukrainian universities $(n=191)$ were included into the sample. The results were processed both quantitatively and qualitatively and demonstrated that students are aware of the need to form soft skills in preparation for their own professional activities. However, more emphasis was placed on them by senior respondents, who, having mastered a large number of specialized subjects and had various types of educational practices, realized the importance of developing skills (soft skills) for personal growth. In this regard, changes are needed in the educational and professional curriculum of the first (bachelor's) level of higher education, where it is important to outline the task of students' soft skills formation as a mandatory component of future professionals' training to meet the requirements of today's labor market.
\end{abstract}

Keywords: conscious attitude, pedagogical activity, professional training, questionnaires, soft skills formation, students, universities. 


\section{Introduction}

One of the main tasks of modern changes in the educational policy of the Ukrainian state is to integrate the standards of the European education area. With regard to the higher education system, it is reflected in the students' number of key competences formation, among which soft skills form a separate group (European Union, 2006; Key Competences for Lifelong Learning, 2007).

Numerous studies of foreign and Ukrainian researchers (Arat, 2014; Hora, Benbow, \& Smolarek, 2018; Koval, 2015; Robles, 2012) note that the main trend in the labor market is the requirement for employers to be experts in the relevant field, possess professional knowledge and skills and necessarily possess soft skills. It is soft skills that will be able to provide future professionals with a high level of competitiveness, which will contribute to their successful joining the workforce and observance its corporate ethics (Gilland, 2009; Lobodynska \& Hrydzhuk, 2020) in interpersonal interaction and achievement in professional activities (Cornalli, 2018). It is especially important to develop soft skills in students of pedagogical universities, who are supposed to interact in their work with different categories: children and their parents, colleagues, staff.

A successful professional is distinguished by the development of the ability to establish communication, work effectively in a team, the ability to quickly make decisions in different situations, resolve conflicts, etc. (Ciappei \& Cinque, 2014). In the Ukrainian education system, this issue has became topical only in recent years, so it is still insufficiently studied, which determines the relevance of scientific research. Its novelty is to clarify a kind of conglomerate: professional training based on the mastery of fundamental and special disciplines, and future specialist's personal development and self-development, which is interpreted as soft skills formation.

The aim of the research is to carry out a theoretical review of the essence of the "soft skills" as a concept and empirical study of the conscious attitude of students (pedagogical specialty 012 "Preschool Education") of Ukrainian universities to master such skills for their future professional activities.

Objectives of the study: 1) to review and analyze the literature on the formation of soft skills in students/graduates of universities and to determine the essence of the studied phenomenon; 2) to characterize the importance, based on the students' opinion of the soft skills formation in their professional training while studying at the university; 3 ) analyze the results and draw conclusions about the peculiarities of the soft skills formation in students from their own point of view. 
Methods. In order to solve the tasks of the study, the following theoretical methods were used - analysis, synthesis, systematization and generalization of the scientific source base of the study, as well as empirical methods - a questionnaire for survey participants (students) and processing of its results.

\section{Literature Review}

An analysis of the literature base suggests that there are different scientific positions on the essence of the concept of "soft skills". In the study of Schulz (2008), these skills are grouped into three varieties: personal qualities, interpersonal skills and additional skills (knowledge). According to the scientist, the main emphasis should be placed on the formation of communication skills that affect the formation of personality in general (ibid). Similar scientific ideas have been expressed by Cornalli (2018), who noted that the effectiveness of modern professional activity is determined by generic skills through the level of mastery of social interaction skills, interpersonal communication, sensitivity and ability to work in a team, which are soft skills (ibid). As noted Arat (2014), Guerra-Báez (2019), Padhi (2014), it is soft skills that contribute to the formation of future specialist's important personal qualities and lead to realization of academic disciplines studying and the generic skills development.

The priority of soft skills is noted during corporate training, which will further ensure the success of career growth (Hora, Benbow, \& Smolarek, 2018). In particular, the most effective soft skills are: "integrity, communication, courtesy, responsibility, social skills, positive attitude, professionalism, flexibility, teamwork, and work ethic" (Robles, 2012, p. 453). The teacher's individuality plays a significant role in the soft skills formation, the main function of which is pedagogical cooperation and the development of each student's personal potential (Briggs, 2015; Haselberger, Oberhuemer, Perez, Cinque, \& Capasso, 2012).

The study of scientific sources of the topic under consideration demonstrated that the issue of soft skills is an important component of university education in different countries. In particular, the following were studied:

- $\quad$ curriculum changes and arrangements to raise students' realization of soft skills development, which has improved learning, as well as a number of benefits in Indian educational institutions (M. Wats \& R. Wats, 2009);

- Malaysia students' and teachers' attitudes towards the necessity to develop soft skills in the training process (Nikitina \& Furuoka, 2012; Ngang, Chan, \& Vetriveilmany, 2015); 
- finding out the effectiveness of the soft skills implementation in teachers' (university graduates) professional activities during their first two years of work in primary schools in the north-eastern region of Thailand (Kanokorn, Pongtorn, \& Sujanya, 2014), as well as studying the level of seven soft skills formation ("critical and problem solving skills, team work skills, ethics, moral and professional skills, leadership skills and innovation invention and development skills") of young teachers in the Secondary Schools of Khon Kaen Secondary Educational Service Area 25, Thailand (Attakorn, Tayut, Pisitthawat, \& Kanokorn, 2014, p. 1010);

- analysis of the influence of soft skills development on the education quality and determination of interest to studying among students of Chinese universities (Yan, Yinghong, Lui, Whiteside, \& Tsey, 2018);

- comparative assessment of the Finnish and Italian students' perceptions about the necessity of soft skills to perform their professional duties successfully due to the requirements of socio-economic development of society (Caggiano, Schleutker, Petrone, \& González-Bernal, 2020).

In Ukrainian science, despite the novelty of the problem, modern researchers (Korniush, 2020; Koval, 2015; Lobodynska \& Hrydzhuk, 2020; Tiutiunnyk, 2015) proved the importance of soft skills and their impact on the content of professional activities in the process of future professionals' training. Thus, without denying the importance of generic skills (Ruokonen \& Sepp, 2020), based on the review of the literature on the essence of the concept of "soft skills" we have come to the following scientific generalizations: the formation of soft skills in university education is recognized as important and obligatory as a component of effective training of future professionals for their professional activities in various fields of work.

\section{Methodology of Research}

Research tools. The main tool was to create a written questionnaire - the questionnaire "What is an ideal preschool teacher?" (see forms.google.com. https://bit.ly/Portret_Vykhovatelia) to diagnose the conscious attitude of students (specialty 012 "Preschool Education") of Ukrainian universities to acquire soft skills for their future professional activities. Information about the survey was disseminated through the social network Facebook (academic groups of subscribers). The content of the questions was based on the order of the relevant ministry - the Ministry of Education and Science of Ukraine from 21.11.2019 № 1456 "On approval of the standard of higher education in specialty 012 "Preschool education" for the first (bachelor's) level of higher education" 
(https://mon.gov.ua/storage/app/media/vishcha-osvita/zatverdzeni\%20standarty/ 2019/11/22/2019-11-22-012doshkilna-B.pdf) according to which 3 types of competencies are defined - these are integral, general and special (professional), including a list of some soft skills (moral values, teamwork, etc.). The results of studies by Attakorn, Tayut, Pisitthawat, \& Kanokorn (2014) and Robles (2012), were also taken into account, specifying the names of soft skills that students should master while studying at university.

The questionnaire contained only 8 questions: one (the first) of which was an open-ended question, which determined the group affiliation of the respondents according to their sample; 6 questions - with a selective answer (three answer options for the choice of respondents, from the list of which it was necessary to choose one) and the last $\left(8^{\text {th }}\right)$ - an open question with a completely free answer. The list of questions (from $2^{\text {nd }}$ to $6^{\text {th }}$ ) lists the names of 12 soft skills (virtue, creativity, teamwork skills, skills of tolerant communication with colleagues, interpersonal communication skills, social skills, flexibility, positive attitude, skills of leadership, moral skills, sensitivity, skills of maternal care for children) and 6 hard skills - professional knowledge, skills and abilities required for pedagogical activities (skills of organizing the educational process in preschool institution, skills of working with sources of educational and scientific information, skills of making an individual program of preschoolers' development, skills of etiquette in communication, a high level of knowledge in preschool pedagogy, child psychology and methods of educating children; skills of innovative forms of work).

Data collection procedure and methods of analysis. The materials of the research were collected by processing the author's questionnaire "What is an ideal preschool teacher?” filled in by students online during September 2020. Questionnaires were processed, namely how many of them were filled in (quantitative analysis) and the content of the answers, their completeness and validity (in the case of open answers) was carried out during October 2020. Analysis and generalization of the results: determination of students' attitude to soft skills, students' understanding of their necessity in their own further pedagogical activity and definition of the most topical, according to respondents, soft skills - carried out in November 2020.

Study sample are described. Participants of the empirical study (questionnaire) were full-time students of 1-4 years of study who are getting the first (bachelor's degree) level of higher education (field of knowledge 01 "Education/Pedagogy") and study on the specialty 012 "Preschool Education" in Hryhorii Skovoroda University in Pereiaslav and Bohdan Khmelnytsky National University of Cherkasy (Ukraine). Due to the specifics of the specialty, only females tend to study on the specialty "Teacher of Preschool Children”, the groups were homogeneous in gender and differed only in age and number according to 
the years of enrollment: $1^{\text {st }}$ year of study -48 participants, $2^{\text {nd }}$ year of study -51 participants, $3^{\text {rd }}$ year of study -45 participants, $4^{\text {th }}$ (graduates) year of study -47 participants. Due to the fact that both universities are state regional institutions of higher education, and therefore carry out equivalent training of students, the participants of the experiment were divided into 4 groups according to their course of study: 1st group $-1^{\text {st }}$ year of study, 2nd group $-2^{\text {nd }}$ year of study, 3rd group $3^{\text {rd }}$ year students, 4 th group - bachelor's graduates.

\section{Results of Research}

Based on the analysis of the questionnaire "What is an ideal preschool teacher?" from the participants $(n=191)$ of the experiment it was found out that all forms were filled in, there wasn't any spoiled questionnaires, and therefore, students showed responsible attitude to their completion. Quantitative results of students' perception of the essence and choice of the importance of skills for the future implementation in their own pedagogical activities in preschool education are presented in Table 1.

Table 1 The Results of a Survey of Students as to the Necessity of Soft Skills Development

$\mathrm{n}=191$

\begin{tabular}{|c|c|c|c|c|c|c|c|c|c|}
\hline \multirow{3}{*}{\multicolumn{2}{|c|}{$\begin{array}{l}\text { № questions and answer options } \\
\text { (according to the questionnaire) }\end{array}$}} & \multicolumn{8}{|c|}{ Indexes } \\
\hline & & \multicolumn{2}{|c|}{ 1-st gr. } & \multicolumn{2}{|c|}{ 2-nd gr. } & \multicolumn{2}{|c|}{ 3-rd gr. } & \multicolumn{2}{|c|}{ 4-th gr. } \\
\hline & & $\mathrm{n}=48$ & $\%$ & $\mathrm{n}=51$ & $\%$ & $\mathrm{n}=45$ & $\%$ & $\mathrm{n}=47$ & $\%$ \\
\hline \multirow[t]{3}{*}{2.} & $\begin{array}{l}\text { A) skills of organizing the } \\
\text { educational process in a } \\
\text { preschool institution }\end{array}$ & 39 & 81.25 & 33 & 64.7 & 19 & 42.22 & 13 & 27.66 \\
\hline & B) virtue & 2 & 4.17 & 9 & 17.65 & 12 & 26.67 & 19 & 40.43 \\
\hline & C) creativity & 7 & 14.58 & 9 & 17.65 & 14 & 31.11 & 15 & 31.91 \\
\hline \multirow[t]{3}{*}{3.} & $\begin{array}{l}\text { A) skills of working with sources } \\
\text { of educational and scientific } \\
\text { information }\end{array}$ & 23 & 47.92 & 7 & 13.73 & 6 & 13.33 & 2 & 4.26 \\
\hline & B) teamwork skills & 21 & 43.75 & 31 & 60.78 & 26 & 57.78 & 21 & 44.68 \\
\hline & $\begin{array}{l}\text { C) skills of tolerant } \\
\text { communication with colleagues }\end{array}$ & 4 & 8.33 & 13 & 25.49 & 13 & 28.89 & 24 & 51.06 \\
\hline \multirow[t]{3}{*}{4.} & $\begin{array}{l}\text { A) interpersonal communication } \\
\text { skills }\end{array}$ & 19 & 39.58 & 8 & 15.69 & 11 & 24.44 & 17 & 36.17 \\
\hline & B ) social skills & 7 & 14.58 & 17 & 33.33 & 17 & 37.78 & 17 & 36.17 \\
\hline & $\begin{array}{l}\text { C) skills of making an individual } \\
\text { programme of preschoolers' } \\
\text { development }\end{array}$ & 22 & 45.84 & 26 & 50.98 & 17 & 37.78 & 13 & 27.66 \\
\hline \multirow[t]{3}{*}{5.} & A) flexibility & 5 & 10.41 & 11 & 21.57 & 12 & 26.67 & 12 & 25.53 \\
\hline & B) positive attitude & 8 & 16.67 & 3 & 5.88 & 7 & 15.55 & 11 & 23.41 \\
\hline & $\begin{array}{l}\text { C) skills of etiquette in } \\
\text { communication }\end{array}$ & 35 & 72.92 & 37 & 72.55 & 26 & 57.78 & 24 & 51.06 \\
\hline
\end{tabular}




\begin{tabular}{l|l|c|c|c|c|c|c|c|c}
\hline 6. & A) skills of leadership & 2 & 4.17 & 5 & 9.8 & 8 & 17.78 & 8 & 17.02 \\
\hline & $\begin{array}{l}\text { B) high level of knowledge in } \\
\text { preschool pedagogy, child } \\
\text { psychology and methods of } \\
\text { educating children }\end{array}$ & 45 & 93.75 & 42 & 82.36 & 29 & 64.44 & 28 & 59.57 \\
\cline { 2 - 9 } C) moral skills & 1 & 2.08 & 4 & 7.84 & 8 & 17.78 & 11 & 23.41 \\
\hline 7. & $\begin{array}{l}\text { A) skills of innovative forms of } \\
\text { work }\end{array}$ & 38 & 79.17 & 12 & 23.53 & 9 & 20 & 6 & 12.77 \\
\hline B) sensitivity & 3 & 6.25 & 18 & 35.29 & 15 & 33.33 & 17 & 36.17 \\
\hline $\begin{array}{l}\text { C) skills of maternal care for } \\
\text { children }\end{array}$ & 7 & 14.58 & 21 & 41.18 & 21 & 46.67 & 24 & 51.06 \\
\hline
\end{tabular}

\section{Symbols:}

gr. - group of respondents

$\mathrm{n}$ - the absolute index - the number of people

$\%$ - relative index

As the indexes in table 1 demonstrate, the answers of the respondents to the questionnaire and their choice of the most important skills from the suggested option were mainly different depending on the year of study. Thus, answering the question: "What skills are the most important in the portrait of a modern teacher of preschool institution?” (2nd in the questionnaire), mostly all students of the 1st group (first year of study) chose the option "A) skills of organizing the educational process in preschool institution" - 81.25\% ( $\mathrm{n}=39)$, which indicates their recognition of the needs for professional hard skills development; a small percentage of respondents, however, determined that it is " $\mathrm{C})$ creativity" $14.58 \%(\mathrm{n}=7)$ and only $4.17 \%(\mathrm{n}=2)$ considered that the most important is " $(\mathrm{B})$ virtue". Instead, in the answers of the students of the 2nd group (second year of study) another option was observed: the option "A" - was chosen by $64.7 \%$ $(n=33)$ of respondents, and options " $B$ " and " $C$ " were distributed equally, they were chosen by $17.65 \%(n=9)$ of respondents, which demonstrated an increase in the soft skills importance in the professional activities of $2^{\text {nd }}$ year students. It was recorded that the respondents of the 3rd group ( $3^{\text {rd }}$ year students), in answers of which a further decrease in the portion of those who preferred hard skills option "A" $-42.22 \%(n=19)$, and an increase in the number of soft skills choices: option "B" was chosen by $26.67 \%(\mathrm{n}=12)$ and accordingly "C" $-31.11 \%$ $(n=14)$, which is a total of $57.78 \%(n=26)$. Thus, more than half of the $3^{\text {rd }}$ year students being surveyed have already realized the importance of soft skills developing in professional training. Instead, the answers of the students of the 4th group (bachelor's graduates) testified to the soft skills priority. Thus, the number of respondents with the answer "A" was only $27.66 \%(\mathrm{n}=13)$, and those who chose the answers "B" and "C" - 72.34\% $(n=34)$ (in fact $-40.43 \%(n=19)+$ $31.91 \%(n=15)$ ), which is only $8.91 \%$ less than the number of students in the 
first group, who identified hard skills to be the most important in the portrait of a modern teacher of preschool institution.

Answering to the question: "What skills are the most important for a teacher to work in a team (in the team of a preschool institution)?" (3rd in the questionnaire), respondents of the 1st group were almost equally determined with the choice of option "A) skills of working with sources of educational and scientific information" - 47.92\% $(\mathrm{n}=23)$ - are hard skills and option "B) teamwork skills" - 43.75\% (n=21) - are soft skills, the latter were joined by those who chose option " $\mathrm{C}$ ) skills of tolerant communication with colleagues" $8.33 \%(n=4)$, which turned out to be scanty. However, choosing the sum of the last two options to answer this question demonstrated that more than half of the respondents ( $1^{\text {st }}$ year students) considered soft skills to be important. It is a very significant result. Respondents from groups $2-4$ recorded a cardinal difference in the choice of answers. This is an extremely sharp decline in the choice of option "A" - it is, in particular, $13.73 \%(\mathrm{n}=7)$ of the total number of the 2nd group; $13.33 \%(n=6)$ - from the 3rd group and only $4.26 \%(n=2)$ - from the 4th group. A significant jump in the number of respondents of the 2nd and 3rd groups is observed in terms of giving priority to the option " $B$ ", it is $60.78 \%(n=31)$ of the students of the $2^{\text {nd }}$ year of study and $57.78 \%(n=26)$ of $3^{\text {rd }}$ year students. Almost the same number in these groups chose the option " $C$ " - 25.49\% $(n=13)$ from the 2nd group and $28.89 \%(n=13)$ from the 3rd group. However, in the responses of graduate students (4th group) the choice between options " $\mathrm{B}$ " and " $\mathrm{C}$ " was distributed almost equally - it is, respectively, 44.68\% $(n=21)$ and $51.06 \%$ $(n=24)$, but with a significant increase, compared with groups 2 and 3, the number of those who gave the choice to the latter.

The difference is also recorded in the analysis of answers to the question: "What skills distinguish the efficiency of a modern teacher of preschool institution?" (4th in the questionnaire). If, according to $1^{\text {st }}$-year students $-45.84 \%$ $(\mathrm{n}=22)\left(1 \mathrm{st}\right.$ group) and $2^{\text {nd }}$ year students $-50.98 \%(\mathrm{n}=26)$ (2nd group) hard skills are defined as such - option " $\mathrm{C}$ ) skills of making an individual program of preschooler's development", then senior students (3rd and 4th) in smaller numbers chose the specified answer. This was 37.78\% $(n=17)$ (Group 3) and $27.66 \%(n=13)$ (Group 4), indicating a trend towards soft skills prioritizing. The definition of their significance is available, starting with the 1st group. The distribution of answer options "A) interpersonal communication" and "B) social skills" is recorded in the following ratios: $1^{\text {st }}$ year students $-39.58 \%(\mathrm{n}=19)$ and $14.58 \%(\mathrm{n}=7) ; 2^{\text {nd }}$ year students $-15.69 \%(\mathrm{n}=8)$ and $33.33 \%(\mathrm{n}=17) ; 3^{\text {rd }}$ year students $-24.44 \%(n=11)$ and $37.78 \%(n=17)$; for graduates $\left(4^{\text {th }}\right.$ year $)$ equally $36.17 \%(\mathrm{n}=17)$. The latter index is a total of $72.34 \%(\mathrm{n}=34)$, which is convincing evidence of a growing trend in realization of students of the 4th group 
in the necessity to develop soft skills compared to students in the 1st and 2nd groups.

Respondents expressed different views in answering to the question: "What skills should a teacher possess in order to establish communication with all the subjects of the educational process?” (5th in the questionnaire). In particular, the answers of students who were in the 1 st group showed that $72.92 \%(n=35)$ of them preferred hard skills - "C) skills of etiquette in communication" and a small number chose options “A) flexibility" or "B) positive attitude" - soft skills: $10.41 \%(\mathrm{n}=5)$ and $16.67 \%(\mathrm{n}=8)$, respectively. A similar trend was seen in the results of the $1^{\text {st }}$ year students' survey, the only difference was the increase in the number of option "A" choices and a decrease in " $\mathrm{B}$ ", although together this figure was the same with the $1^{\text {st }}$ year students. In particular, option " $\mathrm{A}$ " was chosen by $21.57 \%(n=11)$, option " $B$ " - 5.88\% $(n=3)$ and “C” - 72.55\% ( $=37)$. If the $1^{\text {st }}$ year students and $2^{\text {nd }}$ year students demonstrated high indexes of hard skills choice $(72.92 \%$ and $72.55 \%)$, then the respondents of the 3rd and 4th groups demonstrated its decrease: to $57.78 \%(n=26)$ in $3^{\text {rd }}$ year students and up to $51.06 \%(n=24)$ in $4^{\text {th }}$ year students. Instead, the number of choice options for answering " $\mathrm{A}$ " and " $\mathrm{B}$ " has increased, indicating the importance of considering a number of soft skills in building a successful career. The answers were as follows: from the students of the 3rd group, option "A" was chosen by $26.67 \%(n=12)$ and option " $B$ " $-15.55 \%(n=7)$; from the students of the 4th group - option "A" was chosen by $25.53 \%(n=12)$ and option " $B$ " - by $23.41 \%(n=11)$. It was during the graduation course that the number of those who believed that such a skill as "positive attitude" plays a leading role in communication with all the subjects of the educational process increased.

In answer to the question: "What skills are crucial for achieving high results in their own professional activities?" (6th in the questionnaire) based on the results of the analysis, it was found out that the students' choice of options has a similar picture as in the previous question (5th). Thus, in the 1st group the largest number of respondents - 93.75\% ( $=45)$ chose option "B) a high level of knowledge in preschool pedagogy, child psychology and methods of educating children", which indicates the priority of hard skills; the minimum choice fell on the options that indicate soft skills: "A) leadership skills" $-4.17 \%(\mathrm{n}=2)$ and "C) moral skills" $-2.08 \%(n=1)$. A similar distribution was recorded based on the results of the $2^{\text {nd }}$ year students' questionnaires, the difference was an increase to $11.39 \%$ in the answers-choice of soft skills (options "B" and "C"). In particular, option "A" - 9.8\% $(n=5)$, option "B" - 82.36\% $(n=42)$ and option "C" $-7.84 \%$ $(n=4)$. Thus, 2nd year students stood for the choice of hard skills. The shift of emphasis towards focusing on soft skills partially increased in the respondents of the 3rd group, which was $17.92 \%$ more than in the 2nd group and $29.31 \%$ more than in the 1st group. The distribution of choice of answers for $3^{\text {rd }}$ year students 
is as follows: option " $A$ " $-17.78 \%(n=8)$, option " $B$ " $-64.44 \%(n=29)$ and option "C" $-17.78 \%(\mathrm{n}=8)$. In the group of graduates, there was no significant increase in the number of soft skills choices, comparable with the 3rd group (by 4.87\%). However, if we compare with the 1st (34.18\%) and 2nd (22.79\%) groups, the difference is quite significant. The following indexes were recorded in the answers of the respondents of the 4th group: option " $A$ " $-17.02 \%(n=8)$, option "B" $-59.57 \%(\mathrm{n}=28)$ and option " $\mathrm{C}$ " $-23.41 \%(\mathrm{n}=11)$. There was an increase in the number of students who believed that moral skills are crucial for the teachers' professional activities. Nevertheless, all the answers to the 6th question dominate in all groups of respondents who have chosen hard skills.

Answering to the question: "Due to what skills does the teacher interact with children?" (7th in the questionnaire), respondents of the 1 st group ( $1^{\text {st }}$ year students) mostly chose option "A) skills of innovative forms of work" $-79.17 \%$ $(\mathrm{n}=38)$, which indicates that they have identified the priority of hard skills. The other two answers related to soft skills were distributed as follows: "B) skills of sensitivity" $-6.25 \%(n=3)$ and “C) maternal child care skills” $-14.58 \%(n=7)$. Radically different results were recorded in the answers of the 2nd group respondents, in which only $23.53 \%(\mathrm{n}=12)$ preferred option "A", and the others $76.47 \%(n=39)$ (total) chose soft skills - were 35.29\% $(n=18)$ option "B" and $41.18 \%(n=21)$ option " $C$ ". It is the skill of maternal care for children that has become important in the choice of students as one that contributes to successful teaching. This trend, which began in the answers of the $1^{\text {st }}$ year students, persisted and strengthened in the questionnaires of the 3rd and 4th groups. Thus, option "A" was recorded among $3^{\text {rd }}$ year students in $20 \%(n=9)$, and among $4^{\text {th }}$ year students only in $12.77 \%(n=6)$, which indicates a decrease of hard skills importance and giving by senior students an advantage in choosing soft skills. The answers of the respondents of the 3rd group were distributed as follows: option " $\mathrm{B}$ " - 33.33\% $(\mathrm{n}=13)$, option " $\mathrm{C}$ " $-46.67 \%(\mathrm{n}=21)$, which in total is $80 \%$ $(n=36)$ who chose the types of soft skills as a priority. Accordingly, in the answers of the respondents of the 4th group this index increased: option " $\mathrm{B}$ " $36.17 \%(n=17)$, option " $C$ " $-51.06 \%(n=24)$, which is $87.23 \%(n=41)$.

To the last (8th) question of the questionnaire, which was open: "Write your own version of what skills are required to be an ideal teacher of preschool institution", the answers of the respondents were distributed as follows. $1^{\text {st }}$ year students noted that it is the ability to "find an approach to children", "have the skills of the organizational process", etc., which indicates the preference for hard skills. The answers of the $2^{\text {nd }}$ year students recorded the following: "professional competence", "ability to organize children", "awareness of innovative methods of work", as well as a shift in their choice of soft skills: "communication", "tolerance", "creativity", "endurance and patience", "the ability to control their own emotions and behavior", "perception of the position of others". The 
following answers became significant: "the uniqueness of the teaching profession lies in the fact that the structure of his/her professional competence includes personal qualities"; "an ideal teacher is the one who loves his/her pupils like a mother". These answers of the respondents of the 2nd group testified to the growing awareness of their complex combination of professional skills and the identification of soft skills as important ones. According to the results of the $3^{\text {rd }}$ year questionnaires, hard skills were indicated - "ability to approach children", "devotion to the profession", and the list of soft skills was supplemented with the following: “empathy”, "honesty”, “friendliness”, “openness”, “attention”, “ability to self-development". Almost all questionnaires (97\%) indicated that the ideal teacher is distinguished by "love for children". Graduate students (4th group) pointed to the necessity for comprehensive development and noted the following soft skills: "sociability", "sensitivity", "humanity", "generosity", "respect for colleagues", "ability to collaboration and teamwork", "organizational skills", "experience", which testified to their awareness of success in close cooperation with a professional team. However, as in the questionnaires of previous groups, the development of "the ability to work with children's teams" was noted. These results convincingly prove that it is important for students not only to master the content of subjects, but to master the skills necessary for the successful accomplishment of professional functions and effective teaching.

As the data represent only a limited sample of Ukrainian university students, the results cannot be summarized. However, there was a tendency to prioritize the skills of future professional activity in students of speciality "Preschool Education". It proves that the vast majority (respondents of 2-4 groups) are aware of the importance of soft skills development in preparation for their own professional activities and they gave them an advantage while answering to questions in the questionarie. This is due to the fact that with the increase of the scope of specialized subjects and internships, students have chosen exactly the skills that will promote their personal growth - soft skills.

Thus, the peculiarities of the soft skills formation through the prism of students' view was that they, above all, are aware of their importance for professional duties and successful career growth, as well as prioritize them for their own teaching activities. The differences in the answers to the questionnaire of students of different years of study demonstrated the dependence on the amount of mastery of subjects in professional training and pedagogical internships (from the $1^{\text {st }}$ - to $4^{\text {th }}$ year) and in general their conscious attitude to the soft skills formation as the necessity for further professional activity. 


\section{Conclusions and Discussion}

Research on the issue of acquaintance of the students of Ukrainian universities studying in the specialty 012 "Preschool Education" with the soft skills system and determining their importance in the process of professional training has revealed positive results. Significant is the fact that in answering a open question, respondents named the following skills: "communication, friendliness, openness, tolerance, creativity, humanity, sensitivity, sociability, empathy, highly developed personal qualities, etc.”, which are necessary for an ideal teacher of preschool institution. It demonstrates the importance of their understanding of the necessity for personal growth and improvement for future employment and successful career advancement.

Taking into account that soft skills are formed through direct communicative interaction, the following issues remain debatable: 1) what methods and forms of work with students should be used for their development; 2) how to check the level of their formation in students.

We see prospects for further research in making changes in educational and professional curriculum of the first (bachelor's) level of higher education in terms of applying a number of interactive teaching methods to develop students' soft skills, which are necessary as a complex component of professional readiness.

\section{Reference}

Arat, M. (2014). Acquiring soft skills at university. Journal of Educational and Instructional Studies in The World, 4(3), Art. 09. Retrieved from http://www.wjeis.org/File Upload/ds217232/File/wjeis_2014.3_complete.pdf\#page=52

Attakorn, K., Tayut, T., Pisitthawat, K., \& Kanokorn, S. (2014). Soft Skills of New Teachers in the Secondary Schools of Khon Kaen Secondary Educational Service Area 25, Thailand. Procedia - Social and Behavioral Sciences, 112, 1010-1013. doi: 10.1016/j.sbspro.2014.01.1262

Briggs, S. (2015). 30 tips to cultivate soft skills in your students. Open Colleges. InformED: website. Retrieved from https://www. opencolleges.edu.au/informed/features/30-waysto-cultivate-soft-skills-in-your-students/

Caggiano, V., Schleutker, K., Petrone, L., \& González-Bernal, J. (2020). Towards Identifying the Soft Skills Needed in Curricula: Finnish and Italian Students' Self-Evaluations Indicate Differences between Groups. Sustainability, 12(10), 4031. doi:10.3390/ su12104031

Ciappei, C., \& Cinque, M. (2014). Soft skills per il governo dell'agire. Milano: FrancoAngeli.

Cornalli, F. (2018). Training and developing soft skills in higher education. 4th International Conference on Higher Education Advances (HEAd'18) (pp. 961-967). Universitat Polit`ecnica de Val`encia, Val`encia. http://dx.doi.org/10.4995/HEAd18.2018.8127

European Union. (2006). Recommendation of the European Parliament and of the Council of 18 December 2006 on key competences for lifelong learning. Retrieved from http://eurlex.europa.eu/legal-content/EN/TXT/?uri=celex\%3A32006H0962. 
SOCIETY. INTEGRATION. EDUCATION

Proceedings of the International Scientific Conference. Volume I, May $28^{\text {th }}-29^{\text {th }}$, 2021. 406-419

Gilland, S. (2009). Soft Skills and Technical Expertise of Effective Project Managers. Issues in Informing Science and Information Technology, 6, 723-729. https://doi.org/ $10.28945 / 1092$

Guerra-Báez, S. P. (2019). A panoramic review of soft skills training in university students. Psicologia Escolar e Educacional, 23, 1-10. http://dx.doi.org/10.1590/217535392019016464

Haselberger, D., Oberhuemer, P., Perez, E., Cinque, M., \& Capasso, F. (2012). Mediating Soft Skills at Higher Education Institutions: Guidelines for the design of learning situations supporting soft skills achievement. Education and Culture DG Lifelong Learning Programme, European Union. Retrieved from http://www. euca. eu/download. aspx

Hora, M. T., Benbow, R. J., \& Smolarek, B. B. (2018). Re-thinking soft skills and student employability: A new paradigm for undergraduate education. Change: The Magazine of Higher Learning, 50(6), 30-37. https://doi.org/10.1080/00091383.2018.1540819

Kanokorn, S., Pongtorn, P., \& Sujanya, S. (2014). Soft Skills Development to Enhance Teachers' Competencies in Primary Schools. Procedia - Social and Behavioral Sciences, 112, 842-846. doi: 10.1016/j.sbspro.2014.01.1240

Key Competences for Lifelong Learning. (2007). European Reference Framework. Retrieved from https://www.britishcouncil.org/sites/default/files/youth-in-action-keycomp-en.pdf

Korniush, H. (2020). Formuvannia miakykh navychok u studentiv zakladiv vyshchoi osvity v konteksti navchannia inozemnykh mov. Vykladannia mov u vyshchykh navchalnykh zakladakh osvity na suchasnomu etapi. Mizhpredmetni zviazky - Teaching languages in higher education at the present stage. Interdisciplinary Links, 36, 99-110. Retrieved from https://doi.org/10.26565/2073-4379-2020-36-08

Koval, K. O. (2015). Rozvytok "soft skills" u studentiv - odyn z vazhlyvykh chynnykiv pratsevlashtuvannia. Visnyk Vinnytskoho politekhnichnoho instytutu - Bulletin of Vinnytsia Polytechnic Institute, 2, 162-167. Retrieved from http://nbuv.gov.ua/ UJRN/vvpi_2015_2_26

Lobodynska, O. M., \& Hrydzhuk, O. Ye. (2020). Formuvannia sotsialnykh navychok studentiv: problemy y perspektyvy. Naukovyi visnyk Natsionalnoho lisotekhnichnoho universytetu Ukrainy - Scientific Bulletin of the National Forestry University of Ukraine, 30(3), 116-121. https://doi.org/10.36930/40300320

Ngang, T. K., Chan, T. C., \& Vetriveilmany, U. D. (2015). Critical Issues of Soft Skills Development in Teaching Professional Training: Educators' Perspectives. Procedia Social and Behavioral Sciences, 205, 128-133. doi: 10.1016/j.sbspro.2015.09.039

Nikitina, L., \& Furuoka, F. (2012). Sharp focus on soft skills: a case study of Malaysian university students' educational expectations. Educational Research for Policy and Practice, 11, 207-224. https://doi.org/10.1007/s10671-011-9119-4

Padhi, P. K. (2014). Soft skills: Education beyond Academics. IOSR Journal of Humanities and Social Science, 19(5), Ver. VI, 1-3. Retrieved from http://www.iosrjournals.org/iosrjhss/papers/Vol19-issue5/Version-6/A019560103.pdf

Robles, M. M. (2012). Executive perceptions of the top 10 soft skills needed in today's workplace. Business Communication Quarterly, 75(4), 453-465. https://doi.org/ $10.1177 / 1080569912460400$

Ruokonen, I. M., \& Sepp, A. (2020). Finnish Primary and Preschool Teachers Reflecting on Generic Skills: Helsinki University Graduates' Perceptions. SOCIETY. INTEGRATION. EDUCATION. Proceedings of the International Scientific Conference, May 22th-23th. Vol. II, pp. 292-304. http://dx.doi.org/10.17770/sie2020vol2.4993 
Lokhvytska et al., 2021. Soft Skills Formation Through the Prism of University Students' View: Analysis of Survey Results

Schulz, B. (2008). The Importance of Soft Skills: Education beyond Academic Knowledge. Journal of Language and Communication, 2(1), 146-154.

Tiutiunnyk, A. V. (2015). Vykorystannia khmarnykh tekhnolohii ta soft skills v osvitnii diialnosti studentiv ta vykladachiv. Vidkryte osvitnie e-seredovyshche suchasnoho universytetu - Open educational e-environment of a modern university, 1, 134-143. Retrieved from http://nbuv.gov.ua/UJRN/oeeemu_2015_1_15

Wats, M., \& Wats, R. K. (2009). Developing Soft Skills in Students. The International Journal of Learning: Annual Review, 15(12), 1-10. doi:10.18848/1447-9494/CGP/v15i12/46032

Yan, L., Yinghong, Y., Lui, S. M., Whiteside, M., \& Tsey, K. (2018). Teaching “soft skills” to university students in China: the feasibility of an Australian approach. Educational Studies, 45(2), 242-258. https://doi.org/10.1080/03055698.2018.1446328 